\title{
Moving from Face-to-Face Instruction to Virtual Instruction in the COVID-19 Pandemic: Narratives of K-12 Teachers
}

\author{
Patricia Akojie ${ }^{1}$ \\ University of Phoenix, Phoenix, Arizona, USA \\ Imhabibi Laroche \\ College of Central Florida, Ocala, Florida, USA \\ Jane Schumacher \\ University of Phoenix, Phoenix, Arizona, USA
}

\begin{abstract}
The coronavirus pandemic of 2020 took business, education, and the government sectors off guard. On the education front, the problem was interruptions in instruction when alternative forms of instruction are not provided. This study is a narrative of how six certified teachers, with between 1-26 years of teaching experience in $K-12$ grades, and who were recruited through snowball sampling quickly adjusted to providing instruction to students with available and accessible learning management tools during the first two months of the COVID-19 health crisis. Participants shared teaching practices to quickly transition to online education. Teachers drew from their toolbox to reach students using both high and low technology embedded lessons. Participants shared the types of technology and methods used for teaching. Teaching styles included the following approaches: inquiry-based learning, cooperative learning, and kinesthetic approach. The study calls for a crisis management plan for K-12 virtual learning. Recommendations included providing continuous training, so K-12 teachers can effectively teach online.
\end{abstract}

KEYWORDS: Coronavirus, COVID-19 Pandemic, K-12 education, alternative instruction, online learning, technology, distance education, web-based learning.

An outbreak of coronavirus was reported in Wuhan, Hubei, China in December 2019 which is now known as COVID-19 (Coronavirus Disease of 2019). By late January 2020, the World Health Organization ([WHO], 2020) declared the outbreak a public health emergency and a pandemic. By April 2020 over 860,000 people were infected with the virus and over 42,000 died worldwide (John Hopkins University, 2020). The coronavirus took business, education, and the government sectors off guard and required cancellation of various events (Westfall et al., 2020). School leaders believed that school closures would have negative effect on students (Burke \& Dempsey, 2020). Government, businesses, and educational institutions had to make quick decisions both for the welfare of people on a health front and on an education front. The United States Department of Homeland Security formed a Coronavirus Task Force and issued restrictions

${ }^{1}$ Corresponding Author: Faculty, College of Doctoral Studies University of Phoenix, Phoenix, Arizona, USA. E-Mail: pakojie@email.phoenix.edu 
on travel from China to the United States in late January (Samuels, 2020). The Coronavirus Task force declared coronavirus a public health emergency. New York Governor Cuomo declared a state of Emergency on March 7, 2020 (Shvetsova et al., 2020). The President of the United Stated, Donald Trump, declared a national State of Emergency on March 13, 2020 (Ordonez et al., 2020). By late March 2020, many states have declared state of emergencies and stay-at home orders (Wu et al., 2020). The problem is students will lose instructional days if alternative forms of instruction are not provided. Most K-12 schools in the United States resorted to virtual instruction (Delamarter \& Ewart, 2020). There are 3.8 million K-12 teachers in the United States (National Center for Education Statistics, 2016). Most of whom are trained to provide instruction to K-12 students in an on-ground setting. Therefore, little is known about the experiences of educators as they resort to providing virtual instruction.

Lewin (1951) proposed a change theory that entails a three-step process starting with Unfreezing, then Changing, and lastly Refreezing. Unfreezing, as the word implies is the step of freeing up status quo. Schein (1995) described the three sub-steps in Unfreezing. The first step is a sense of dissonance or discomfort, frustration, which prompts the person to search for new ways or knowledge to deal with the current discomfort (survival anxiety) followed by creation of psychological safety or cognitive redefinition (Schein, 1999). Individuals at this stage are dissatisfied with the present situation and strive to survive by finding new survival mechanism. The Changing phase is a conscious and deliberate execution of steps towards reaching a goal. That is, the implementation of a plan to reach a goal. The changing stage could therefore involve experimenting to find a new normal. Once signs of positive reinforcement that changed the landscape is reached, the last step of Refreezing comes next (Kritsonis, 2005; Schein, 1995). To Refreeze, there must be plans to sustain the change such as providing support.

The COVID-19 pandemic that erupted worldwide in 2020 radically impacted the way teachers, preschool-postgraduate studies, approached teaching and learning. Teachers had to respond immediately to transferring their curriculum, instruction, and assessment practices from face to face in classrooms across the United States to being present and actively engaged in virtual learning environments (Ransdell \& Rieck, 2020; Stewart, 2020). Even those schools or classroom environments that already were operating in blended or hybrid ways, discovered the need for teachers to enhance their instructional skills and build upon existing knowledge and expertise (Rapanta et al., 2020). The social and cognitive instructional practices noted by Rapanta et al. (2020) required an immediate change from face-to-face instruction to instruction in a virtual environment. The adaptation of curriculum materials was studied by Rovai and Downey (2010) and Grant and Thornton (2007), who found that previously written curriculum for a face-to-face classroom had to be adapted in terms of instructional differentiation to meet student needs and that also meant adaptation of formative and summative assessments used to measure student growth. The need to engage in a new set of professional skills could cause stress for teachers, students, and their families. However, with planning, the new skills could be useful as with the case of Walker et al. (2018) project that highlighted how communication is enhanced in virtual small groups.

This study explored the experiences of six certified K-12 teachers in the United States as they transitioned from on-ground to online medium of education during the COVID-19 pandemic. Based on the teachers' narratives, the study identified strategies for online instruction for K-12 students during emergencies. The study was guided by these questions: How did you provide instruction to students during the COVID-19 shut down? What technology or resources did you use? What have you learned about providing instructions to students outside of a school building? The study identified learning management tools used in $21^{\text {st }} \mathrm{K}-12$ schools. The familiarity of teachers with digital technology and their willingness to accept delivery knowledge through digital 
technology. The study gathered teaching practices for quick transitioning to online education in an emergency in K-12 schools.

\section{Methodology}

Narrative inquiry is a qualitative research design that studies the experiences of participants through a narrative form (Clandinin, 2016). The goal of the study was to explore the experiences of K-12 teachers, to identify common characteristics through the teachers' experiences, as they regrouped to provide alternative forms of instruction during the COVID-19 pandemic. Narrative inquiry is a way of understanding, through the stories of participants, the experiences related to moving from face-to-face instruction to virtual instruction. Because the research focused on understanding personal meaning and individual human experiences (Lindsay \& Schwind, 2016), narrative inquiry was therefore determined to be an appropriate research design. Emergent themes were identified based on the captured stories from the interviews.

The population of this study were K-12 teachers from a southeast region of the United States. A non-probability snowball sampling of six certified teachers participated in the study and while the southeast region was common to all participants in the study, the six participants represented different experiences in teaching. The qualitative study explored teachers' perceptions regarding providing instruction to K-12 students in the early months of the COVID-19 crisis (March to June 2020). Using a narrative approach, participants were interviewed using open ended questions (See Appendix A). The interview questions were reviewed by two experts in the field of educational technology. The questions were piloted to two K-12 teachers to make sure there was no misunderstanding. The responses of the two pilot interviews were not included in the results of the study. University Institutional Review Board granted permission to collect data.

Prospective participants were recruited via email flyers. The email recruitment script described the purpose of the study and participation involvement. K-12 teachers that met predetermined inclusion criteria were selected for participation. The criteria for participation include a K-12 certified teachers involved in instruction from March 2020 to June 2020. The COVID-19 pandemic that propelled all teachers into a distance learning model impacted the way data was collected for the study. The pandemic crisis caused mandatory shut-down of most schools. The initial plan was to interview teachers face to face, but the contingency plan resulted in interviews conducted by video conferencing through Zoom, Google Meets, Microsoft TEAMS 365 , or telephone, whichever is convenient for volunteers. Through the Informed Consent, participants were informed that their information and participation in the study would be confidential, and this was maintained by assigning pseudonyms. Because of social distance mandates, creative ways of signing the informed consent electronically and confidentially were also devised.

After obtaining consent from participants, the interview process commenced. Participants who met the inclusion criteria were contacted, and interviews scheduled. The interviews were semistructured, allowing a more natural conversational tone to the interview. The interviews lasted 45 minutes to one hour, depending on the amount of detail the participants provided and the number of follow-up questions to the participant responses. The interviews were recorded. The researchers also took handwritten notes during the interviews. The researchers used Microsoft Excel to assist with categorizing, coding, and finding emerging themes from the data by highlighting key words and phrases seen repeatedly throughout the data sets. This plan required multiple reads and researchers' reflections as themes are linked to the study's research questions. 


\section{Demographics}

Ten certified K-12 teachers responded to the call to participate in the study, however six met the inclusion criteria. Pseudonyms were assigned to each of the six participants to ensure that confidentiality would be maintained. The six participants were all from the southeast region of the United States and met the criteria for inclusion in the study (see Table 1).

\section{Table 1}

Participant Demographics

\begin{tabular}{|c|c|c|c|c|c|c|}
\hline Name & Region & Race & $\begin{array}{l}\text { Years of } \\
\text { Teaching } \\
\text { Experience }\end{array}$ & $\begin{array}{l}\text { Grade } \\
\text { level } \\
\text { taught }\end{array}$ & $\begin{array}{l}\text { Subject } \\
\text { area taught }\end{array}$ & $\begin{array}{l}\text { Online } \\
\text { teaching } \\
\text { experience }\end{array}$ \\
\hline Leela & $\begin{array}{l}\text { Southeast } \\
\text { USA }\end{array}$ & $\begin{array}{l}\text { Asian } \\
\text { American }\end{array}$ & 16 & $6-8$ & $\begin{array}{l}\text { Language } \\
\text { Arts }\end{array}$ & None \\
\hline Ruby & $\begin{array}{l}\text { Southeast } \\
\text { USA }\end{array}$ & $\begin{array}{l}\text { African } \\
\text { American }\end{array}$ & 25 & $1-6$ & $\begin{array}{l}\text { Special } \\
\text { Education }\end{array}$ & None \\
\hline Ruth & $\begin{array}{l}\text { Southeast } \\
\text { USA }\end{array}$ & $\begin{array}{l}\text { African } \\
\text { American }\end{array}$ & 1 & K-6 & $\begin{array}{l}\text { All } \\
\text { subjects }\end{array}$ & None \\
\hline Martha & $\begin{array}{l}\text { Southeast } \\
\text { USA }\end{array}$ & White & 14 & $\mathrm{~K}$ & $\begin{array}{l}\text { All } \\
\text { subjects }\end{array}$ & None \\
\hline Morgan & $\begin{array}{l}\text { Southeast } \\
\text { USA }\end{array}$ & White & 22 & $7-8$ & Science & None \\
\hline Erin & $\begin{array}{l}\text { Southeast } \\
\text { USA }\end{array}$ & White & 12 & $6-12$ & Biology & 2 years \\
\hline
\end{tabular}

Leela, an Asian American woman, taught 10 years in a public school in Malaysia before migrating to the United States. Since arriving to the States, she also taught six years as an adjunct faculty in a small private university in the southeast region and five years in a public-school system in a Kentucky rural school. She presently teaches in a middle school with a population of about 600-650 students. Leela taught six classes of which four are Language Arts classes and two Reading Edge classes. She has approximately 20-35 students in a class.

Ruby has been teaching for 25 years. Her areas of certifications are general education, grades one to six, and special education K-12. Ruby teaches in an urban elementary school located in the southeastern region of the United States. School population is about 600 students. Ruby teaches four classes as a Special Education Resource Teacher.

Ruth is a first-year special education K-12 and general education K-6 teacher. Ruth teaches in an urban school located in the Southwest region. Ruth shared that 2020 was her first time teaching online. However, she took her college coursework online, because of the online learning experience, she had "a good idea of what it [online teaching] should look like." Ruth has been taking online classes since 2003. She graduated from an online university.

Martha started teaching in 1995. Martha taught grades 8-12 science classes for nine years. Then, she became a stay home mother with her son for 6 years. When Martha's son started kindergarten eleven years ago, she wanted to be back in the classroom, so she returned to teaching. 
Since returning to teaching, she taught chemistry for 5 years in a rural school in the southeast region of the United States. Martha is now a school counselor at the same school, working with students in and out of a classroom setting. Martha has no online teaching or learning experience before COVID-19 pandemic.

Morgan has taught for 22 years. Morgan teaches 7th and 8th grade Science in a rural school located in the southeastern region. Classes include Chemistry, Physical Science, Biology, and Life Science. Morgan does not have online learning or teaching experience before COVID-19 pandemic.

On the other hand, Erin is a certified Blackboard online instructor with 12 years teaching experience. Erin teaches in a rural school located in the southeastern region. She teaches 6-12 grade science with a concentration in biology, Erin has six years college adjunct experience as a biology faculty. Erin has two years online teaching experience, but no online learning experience before COVID-19.

\section{Results}

\section{Technology and other resources used during COVID-19}

Some K-12 schools/school districts in the southeast region of the United States in which this study was conducted, went hybrid, defined as a situation where some students were allowed to come back to school and were socially distanced from each other. Other schools were totally virtual. Instruction that was moved to an online platform were delivered via platforms like Zoom and Google classroom. Schools also provided teachers with access to platforms like Schoology and Microsoft Teams 365 suite. See Figures 1 and 2 for the array of learning management and software tools used for instruction.

\section{Figure 1}

Learning Management Tools for Instruction

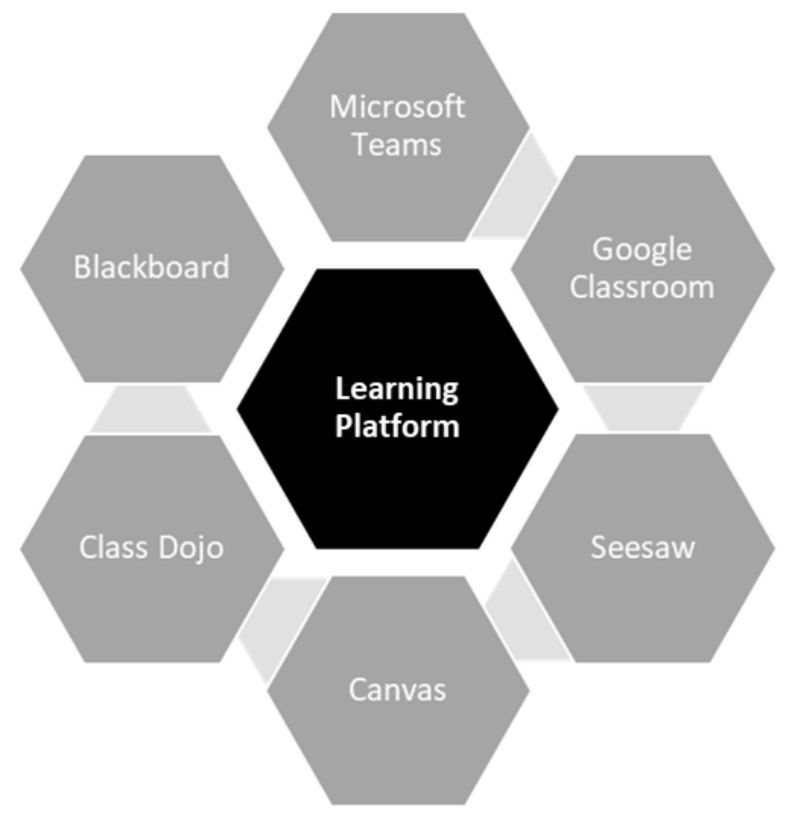


Students had district issued technology devices such as computers and headphones. Teachers used platforms provided by district to provide instruction. Figure 2 shows examples of software the teachers shared during interviews. Many used Microsoft Team Suite and Zoom video communication. Students used Google Classroom to complete assignments. Some teachers developed their own videos or used existing YouTube videos and Apple iMovie to provide instruction. In Leela's words: "My assignments primarily came from the textbook, resources I created, or found online, YouTube videos or videos provided by AP College Board." Some teachers videoed themselves and shared the videos as a lesson. Participants shared that using videos allowed the distance learning students to "feel like a part of the class and to hear the questions of their classmates." Morgan created videos but commented: "I do not wish to go live with classes." Some teachers on the other hand, went live every lesson period and found great results. That means, teachers took individual initiative to connect with their students. Teachers did not only focus on their students, but they also found a way to involve parents. Leela shared information to students and parents about upcoming events via KiNVO, a software the district provided to communicate with parents and guardians. While many participants used technology to deliver instruction, some did not have the capability to go live each day from home, so they sent students instructional websites and made hardcopy educational packages for students who may not have internet access or the capacity at home like them.

\section{Figure 2}

Software for Instruction

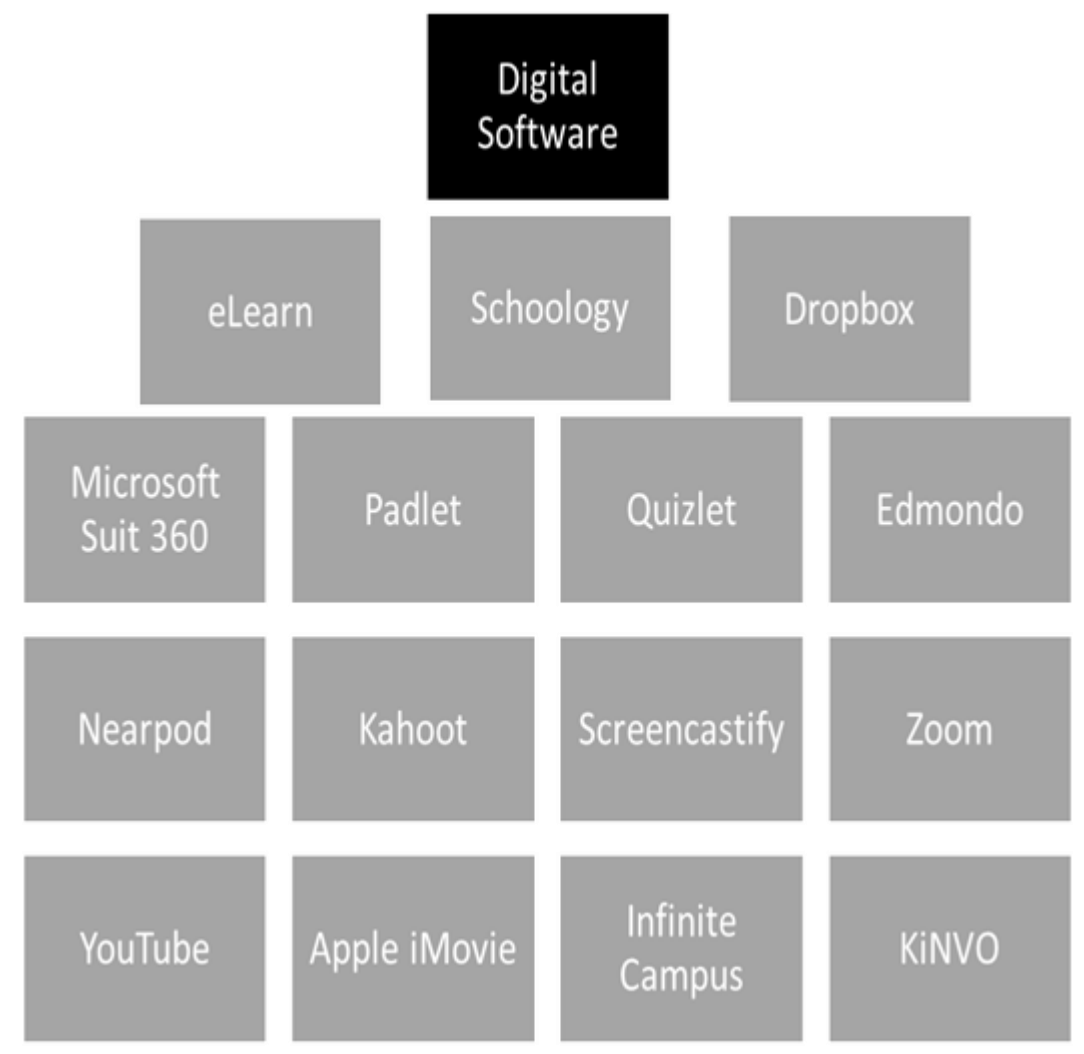




\section{Providing Instruction during COVID-19}

Participants used Inquiry Based learning, Project Based Learning methods, and Jigsaw technique. These methods took various forms such as having a "pet day" and "show and tell" on designated google meet days. Ruth shared that she taught her students in small groups and focused on Social Emotional Learning for her students to become resilient despite what is going on around them. She used a variety of ways to measure mastery of content such as recording student activities. Showing mastery also included using digital exit tickets and portfolio documentations. Goal setting sessions were used by others. All teachers provided students more time to process information and turn in assignments. Participants provided students with "review and practice guides for reinforcements" (Morgan).

Some of the participants felt prepared and some did not feel prepared to provide instruction during the COVID-19 crisis. Teachers with previous online teaching and/or learning experience felt prepared to provide instruction. In Erin's words, "I was prepared because I was a certified Blackboard online instructor." Some study participants shared that they received a mini training for one to two days that briefly covered the technology aspect of distance learning. They also shared concern for the safety of staff and students. It was interesting that providing safety and cleaning supplies were seen as positive part of preparedness by some participants.

Teachers shared some challenges such as students not attending live video sessions and not signing-in to complete assignments. Some students were bored. Teachers in rural areas expressed that many students did not have internet at home, which caused the students to fall behind. Students having little or no parental support. There were technical issues with servers crashing. Access to technology and $\mathrm{Wi}-\mathrm{Fi}$, and the issue of high-risk students without accountability or support were all part of the challenge. The biggest challenge was the time and the demands of administrators. In Leela's words "I don't think the administrators have the tools for the demands they are making for online teaching." Ruby said: "There is a lot going on with online teaching. Difficulty with annexing some online tools and break down in internet services." Leela and Morgan shared that,

At first it was difficult. I didn't know what I could do with technology that was provided for me. Sending and getting assignments was a nightmare. It was difficult for me to gather up the assignments the students gave me because they would submit it in various ways. However, I learned how to use OneNote book. That software has been a great help. I also learned how to create my own videos. (Leela)

Going live with a classroom during our class was very complicated regarding my technology setup in my classroom and I also did not feel comfortable using that aspect of online, so I did not use it. Online for us also included using YouTube/other videos so I utilized those along with the textbook and other resources. It was very stressful trying to prepare for online students and in-class work for students. (Morgan)

It was also a nightmare for the kids. They had no idea what to do. They were sending in assignments in every way they can. Also, some kids had no computer. The district had promised computers that was delayed in delivering the machines. Some kids had no internet. Some kids do not have any supervision and guidance. Some parents also are so overwhelmed that both the children and the adults have shut down. This caused a lot of kids 
to fail around the first quarter. Some kids think that they are on extended summer break and are not doing anything! (Leela)

Ruby shared that "some of the students can follow direction while teaching is going on. While there are many students who just join the class, confused, and did not know what to do. Their families don't know how to help them either." Though participants were creative and used diverse ways to provide instruction for their students, they expressed that the process could be improved. Leela expressed: "I think the biggest need for improvement is to use the software that is like what K-prep would use. The children and the teachers must get an idea of the questions and answers to be presented." Martha's school used Teams 365, she expressed that "When talking with a group of students greater than five, you cannot see everyone. I like how zoom focuses on the person talking, but [Microsoft] Teams does not." Ruth and Morgan expressed that "Teachers needed more training to increase efficacy" such as "Easy steps for usage" (according to Ruth). Leela saw virtual learning as "an additional stress. I also think the way we set Learning Checks must also change. Also, the demands to keep up with their attendance is extremely stressful. Some students log in, but they do not turn on their cameras, so this makes it difficult for us to gauge their interest even if they are in class." Participants expressed technical difficulties, not enough practice for students, and no online training for students and teachers.

\section{Study participants learned to adjust}

Moving from face-to-face instruction to virtual instruction aligned with Lewin's (1951) change theory as exemplified below:

Stage1-Unfreeze example: "There is a lot going on with online teaching. Difficulty with annexing some online tools and break down in internet services. . . . Not very prepared." (Ruby)

Stage 2-Change example: "I learned how to use OneNote book. That software has been a great help. I also learned how to create my own videos." (Leela)

Stage 3-Refreeze example: "We received two days of professional development training on the use of the Teams Classroom." (Martha). "Provide more opportunities for professional development in various subject." (Erin)

It is such narratives that informed our findings and represented the voices of the teachers interviewed during the initial months of the pandemic. To address what has been learned about providing instructions to K-12 students outside of a school building, the following two themes were identified: teacher's resilience and training for online instruction.

Theme 1: Teacher's Resilience. Teachers were pliable by reaching into their instructional toolboxes. Participants creatively used resources at their disposal to reach their students. Forms of instruction and assessments for K-12 that worked for participants during the COVID-19 included video chats, small group lessons, one-on-one chats, and portfolios. Student centered lessons was common among the participants, where the students produce their own projects and presented them. Teachers used YouTube clips for content and online writing websites to help students with writing assignments in Morgan's words "I used videos-to explain topics." For students who did not take books home before the shutdown, they were provided text links. Some participants prepared hard copy lesson packages delivered at students' homes as needed. Cooperative projects where 
students worked online as a group were part of the teaching and learning method. Some other participants used interactive websites for reinforcement and learning of concepts. For assessment Ruth expressed that "portfolios allow students to document their work and provide evidence of growth. STEM/STEAM projects can be combined with other disciplines and allows students to work on cooperative work groups online, students can work on projects in breakout rooms."

Theme 2: Training for Online Instruction. A second theme that emerged was a yearning for additional training. A factor that was not considered by schools is teachers' cultures and home environments, that is, the capabilities the teachers had to instruct in their home environments. A participant shared that, teachers were "ordered from our classrooms with only one-day notice to get items from our classrooms and construct some digital lessons. Most of our trainings regarding Google Classroom and Web2.0 tools were informative, and not to put to actual use." This meant that many teachers did not have Google Classroom set up and were unable to make the transition when they went home. There were participants who did not have sufficient internet access or computer hardware to administer online lessons at home but instead made educational packets delivered to students' homes. Participants expressed that online learning was not meeting the needs of their students but each week, they were learning more about how to improve instruction, such as providing students the opportunity to learn through various means including hardcopy alternative to keep students academically involved, but as Leela expressed: "still have a long road ahead of us to become anywhere near successful, and our eyes are now open to many issues to resolve." Erin completed a course one year prior to COVID-19 to become a certified Blackboard online instructor. During COVID-19, some participants received brief training. Martha received only two days of professional development training on the use of Microsoft Teams for classroom use before COVID-19 outbreak. Erin was provided professional development for Schoology and Google Meet. Morgan was "briefly introduced to Teams". Ruth was introduced to Canvas. Ruby had professional training on cooperative learning, inquiry-based instruction, and differentiation. Leela expressed: "the instruction that we received during COVID-19 was how to make videos and an introduction to Office 365." Participants hoped the district will provide more training in the future especially with the use of technology and online platforms.

\section{Discussions and Recommendations}

K-12 educational institutions found themselves amid the widespread coronavirus lockdowns to continue to provide instruction. Coupled with the asymptomatic infectious nature of the virus, teachers had to quickly design alternate forms of instruction outside the four walls of school buildings like the participants in Ransdell and Rieck's (2020) study. In our study, some parents become teachers at home to assist their children. Though parents wanted to help, they lacked the pedagogical and content knowledge (Garbe et al, 2020). It was crucial to maintain communication with students and to continue with education, so students did not lose out on the planned curriculum. Apart from phone conversation, the internet had resources such as Google Apps, and social media tools to make this possible. But how prepared where students, parents, and teachers, to use these tools? The narratives of teachers in this study just like those in a survey of schools in Ireland (Burke \& Dempsey, 2020), found that not all teachers have the technical skills and not all students have the technology required for virtual distance education amid COVID-19. Schools had different platforms for learning within the four walls of the institutions, but with the health pandemic, it was not easily for teachers to provide the same form of instruction. Some teachers found themselves creating alternative forms of instruction to use in their visual classroom like the "instructor-made videos" described by Andrei and Buckley-Marudas (2019). Teacher presence and active engagements in supporting virtual instruction literally changed the way 
teachers and students interacted (Park \& Kim, 2020). Both teachers and students had to quickly adapt to learning a whole new set of best practices in curriculum, instruction, and assessment. Some of these expanded areas of skill building for teachers who were learning how to function in virtual classrooms included: building relationships, honoring student challenges in knowing how to work effectively online, creating a sense of collectivism, and engaging in content support while building community within the virtual classroom. Participants planned learning activities that allowed students to express their learning in multiple formats such as show and tell, presentations, written papers, videos, and other technologies or formats within which students demonstrated knowledge and skill. Instructors plan lessons, including choice for students, to use their voices and thoughts in synchronous learning experiences to positively impact student motivation and academic achievement as suggested by authors like Rienties and Rivers (2014).

Emergency preparedness plans for K-12 schools like the recommendations of Chung et al. (2009) are for emergencies like terrorism and natural disasters. Health crisis that directly affects schools are rare, as a result, a consistent preparedness plan was not in place in participants' schools. The 2020 COVID-19 pandemic and the inconsistent preparedness plan and policy of schools, especially $\mathrm{K}-12$, is proof that the United States has an opportunity to adopt a continuous improvement plan with best practices on tackling this difficult challenge. Perrotta (2020) asks if once the crisis is over, will things go back to the way it was, or will there be an increase in the adoption of online learning? Robertson (2017) noted that crisis management plans need to be rehearsed and not shelved. Educators are therefore challenged to create a crisis management learning environment plan. Lewin's (1951) change theory set the theoretical foundation for models and processes for social change at an individual or group level. The crisis instructional plan for schools must take into consideration factors like culture, learning style, and social economic status of the students. While learning at a distance may work for some students, for others, it a challenge and may result in a wider learning gap (Lamb et al., 2020). Challenges included family social economic status and the skill level of students. These are factors to consider when providing education at a distance. The ability to access and make effective use of technology is dependent on a student's socioeconomic status (Chen et al., 2019). With the lack of access to technological resources, educators continue to face challenges with providing consistent learning opportunities across all student demographics. Teachers will also need continuous training in online teaching. During a crisis, the transition from traditional to online education environment increased the existing inequity. Bates and Sangra (2011) stated that the technology infrastructure requires investment, maintenance, and new activities to keep learning productive. Pan and Franklin (2011) stated that administrative support is needed to create self-efficacy to use the new Web 2.0 tools. Professional development is a key component in creating comfort and efficiency to change school culture. The Technology, Pedagogical, and Content Knowledge (TPACK) framework could be an essential component in directing teachers' professional development technology programs regarding providing virtual learning.

\section{Limitations and Conclusion}

A limitation of the study was that data collected was based on the experiences of participants during the first few months of COVID-19, from March 2020-June 2020. Due to the pandemic, data was collected through various digital means instead of face-to-face. Because teachers were very busy transiting from virtual learning, only six participants total were interviewed. Some were contacted via snowballing. Since, these results were based on the first few months of the COVID-19 pandemic, the results are not generalizable. However, the study contributes to a valuable growing body of educational research by creating knowledge, 
understanding, and adding to teachers' repertoire for teaching K-12 online during times of emergencies. Teachers drew from their toolbox to reach students in a variety of ways such as:

- Inquiry based learning: where students are facilitator and personal models of assignments were provided.

- Cooperative learning - where student are facilitator and delegator. Using student centered lessons.

- High tech approach- here computer and technology were used in instruction such as videos, interactive websites, and learning management platforms.

- Low tech approach to learning- students taking note and retaining lesson through home delivered lesson packages, small group lessons, one-on-one chats, and portfolios

- Kinesthetic learning - hands on home activities and "show and tells".

This study provides a baseline for future research to validate the need for K-12 teachers to make a pedagogical shift towards online learning supported by technology tools during times of emergencies. Organizational change is inevitable (Spector, 2016), educational technology leaders should embrace it and learn how to initiate and manage change, if not, we are doing our communities and schools a disservice. Spector (2016) suggested to begin with an assessment of what problems exist, and what problems are likely to occur. Harrell and Bynum (2018) made a point that when using technology-based instruction, issues of equity for socioeconomically disadvantaged need be considered. Equity in instruction needs to include those students who find it almost impossible to learn in a distance learning environment.

\section{Acknowledgement}

We thank Dr. Mansureh Kebritchi (Chair, Center for Educational and Instructional Technology Research, University of Phoenix) for assistance in reviewing interview questions. Her willingness to give her time so generously is much appreciated.

\section{References}

Andrei, E., \& Buckley-Marudas, M. F. (2019). It does not need to be perfect! To teacher educators' quest to enhance online instruction with videos. Networks: An Online Journal for Teacher Research, 21(2).

Bates, A. W., \& Sangra, A. (2011). Managing technology in higher education: Strategies for transforming teaching and learning. Jossey-Bass

Burke, J. \& Dempsey, M. (2020). COVID-19 practice in primary schools in Ireland report. National University of Ireland.

Chen, T., Wanberg, R. C., Gouioa, E. T., Brown, M. J. S., Chen, J. C.-Y., \& Kraiger, J. J. K. (2019). Engaging parents involvement in K - 12 online learning settings: Are we meeting the needs of underserved students? Journal of E-Learning \& Knowledge Society, 15(2), 113-120. https://doi.org/10.20368/1971-8829/1563

Chung, S., Danielson, J., \& Shannon, M. (2009). School-based emergency preparedness: A national analysis and protocol. https://cchealth.org/ems/pdf/ems_children_schoolbased_protocol.pdf

Clandinin, D. J. (2016). Engaging in narrative inquiry. Left Coast Press. 
Delamarter, J. \& Ewart, M. (2020). Responding to student teachers' fears: How we're adjusting during the COVID-19 shutdowns. Northwest Journal of Teacher Education, 15(1). https://doi.org/10.15760/nwjte.2020.15.1.3

Garbe, A., Ogurlu, U., Logan, N., \& Cook, P. (2020). COVID-19 and remote learning: Experiences of parents with children during the pandemic. American Journal of Qualitative Research, 4(3), 45. https://doi.org/10.29333/ajqr/8471

Grant, M. R., \& Thornton, H. R. (2007). Best practices in undergraduate adult-centered online learning: mechanisms for course design and delivery. MERLOT Journal of Online Learning and Teaching, 3(4), 346-356.

Harrell, S., \& Bynum, Y. (2018). Factors affecting technology integration in the classroom. Journal of Educational Leadership, 5, 12-18.

John Hopkins University (2020). Coronavirus resource centre. https://coronavirus.jhu.edu/

Kritsonis, A. (2005). Comparison of change theories. International Journal of Scholarly Academic Intellectual Diversity $8(1)$.

Lamb, S., Maire, Q., Doecke, E., Macklin, S., Noble, K \& Pilcher, S. (2020) Impact of learning from home on educational outcomes for disadvantaged children. Centre for International Research on Education Systems and the Mitchell Institute, Victoria University.

Lewin K. (1951) Field theory in social science. Harper and Row.

Lindsay, G. M., \& Schwind, J. K. (2016). Narrative inquiry: Experience matters. Canadian Journal of Nursing Research, 48(1), 14-20. https://doi.org/10.1177/0844562116652230

National Center for Education Statistics. (2016). Digest of Education Statistics. https://nces.ed.gov

Ordonez, F., Naylor, B., Keith, T. \& Rascoe, A. (2020). President Trump declares national emergency as coronavirus pandemic grows. National Public Radio [Online] Available at: https://www.npr.org/2020/03/13/815420295/trump-to-discuss-coronavirus-amid-growingcrisisscrutiny-of-his-response

Pan, S. C., \& Franklin, T. (2011). In-service teachers' self-efficacy, professional development, and Web 2.0 tools for integration. New Horizons in Education, 59(3), 28-40.

Park, C., \& Kim, D. (2020). Perception of instructor presence and its effects on learning experience in online classes. Journal of Information Technology Education, 19, 475-488. https://doi.org/10.28945/4611

Perrotta, C. (2020). Coronavirus quarantine could spark an online learning boom. https://theconversation.com/coronavirus-quarantine-could-spark-an-online-learningboom-

Ransdell, S., \& Rieck, J. (2020). Closing the distance in distance learning: Strategies to increase intrinsic motivation in the time of COVID-19. Distance Learning, 17(3), 87-90.

Rapanta, C., Botturi, L., Goodyear, P., Guardia, L., \& Koole, M. (2020). Online university teaching during and after the COVID-19 crisis: Refocusing teacher presence and learning activity. Postdigital Science and Education, 2, 923-945. https://doi.org/10.1007/s42438-02000155-y

Rienties, B., \& Rivers, B. A. (2014). Measuring and understanding learner emotions: Evidence and prospects. https://lace.apps.slate.uib.no/publications/learning-analytics-andemotions.pdf

Robertson, N. C. (2017). Principal Preparedness for Crisis Management in Urban High Schools [ProQuest LLC]. In ProQuest LLC.

Rovai, A. P., \& Downey, J. R. (2010). Why some distance education programs fail while others succeed in a global environment. Internet Higher Education, 13(3), 141-147. https://doi.org/10.1016/j.iheduc.2009.07.001 
Samuels, B. (2020). White House announces task force to monitor coronavirus. The Hill https://thehill.com/policy/healthcare/480627-white-house-announces-task-force-tomonitor-coronavirus

Schein, E. H. (1995). Kurt Lewin in the classroom, in the field, and in change theory: Notes toward a model of managed learning. https://dspace.mit.edu/bitstream/handle/1721.1/2576/SWP3821-32871445.pdf

Schein, E. H. (1999). Kurt Lewin's change theory in the field and in the classroom: Notes toward a model of managed learning. Reflections, 1(1), 59-74. https://doi.org/10.1162/152417399570287

Shvetsova, O., Catalano, M., Chu, H., Dumond, G. K., Muftuoglu, E., Ozutemiz, H., Sadykova, A., \& Riggs, T. (2020). Policy error and policy rescue in COVID-19 responses in the United States and United Kingdom. Working Papers Series. 3. https://orb.binghamton.edu/working_paper_series/3

Spector, M. J. (2016). Foundations of educational technology: Integrative approaches and interdisciplinary perspectives. Routledge.

Stewart, M. (2020). Business schools look to changes in curriculum to prepare students for the challenges of a global pandemic. INSIGHT into Diversity, 96(1), 42-43.

Walker, R. C., Cardon, P. W., \& Aritz, J. (2018). Enhancing global virtual small group communication skills. Journal of Intercultural Communication Research, 47(5). 421-433. https://doi.org/10.1080/17475759.2018.1475292

Westfall, S. S., Tauber, M., Dodd, J., Mazziotta, J., Bender, K., Mcniece, M., Herbst, D., Keating, C., Lesley, D. S., Maslow, N., McNeil, L., Sheeler, J., \& Young, S. (2020). Special Report Coronavirus in America. People, 93(13), 36.

World Health Organization Newsletter (March 11, 2020). WHO Director-General's opening remarks at the media briefing on COVID-19 - 11 March 2020. https://www.who.int/dg/speeches/detail/who-director-general-s-opening-remarks-at-themedia-briefing-on-covid-19---11-march-2020

Wu, J., Smith, S., Khurana, M., Siemaszko, C. \& DeJesus-Banos, B. (2020). Stay-at-Home orders across the country. ABC News. https://www.nbcnews.com/health/health-news/here-arestay-home-orders-across-country-n1168736

\section{Appendix A}

\section{Interview Questions: Providing Instruction during COVID-19 Crisis}

1. Share your teaching background such as years of teaching and areas of certification.

2. What type of school do you teach - Rural or Urban?

3. What is the estimated population of the students in the school?

4. How many students or classes/courses do you teach?

5. How prepared were you in providing instruction during a crisis like the COVID-19?

6. How did you deliver instruction to your students at the time of the COVID-19?

7. What learning platform does your school have in place?

8. Share your experience with online teaching.

9. Share your experience with online learning.

10. What digital software did you use to provide instruction?

11. What video software did you use to provide instruction?

12. What internet software did you use to provide instruction?

13. What digital software did your students use to complete assignments? 
14. What improvements (if any) could be made to these various methods of providing instruction?

15. What instructional training did you receive before COVID-19?

16. What instructional training did you receive during COVID-19?

17. What plans does the school have for future training?

18. Share additional/alternative teaching strategies you used that improved students' learning in online settings.

19. Share alternative effective teaching strategies in online settings that you wish to use in the future and couldn't use previously.

20. Share challenges that you encountered when teaching in online settings.

21. Share your top five alternative forms of instruction for teaching K-12 online. Give reasons for the top five.

\section{Notes on Contributors}

Patricia Akojie, PhD, M.Ed., M.Sc. earned both her M.Sc. (Instructional Design) and an Educational Technology Certificate from Western Kentucky University, Bowling Green, KY. A $\mathrm{Ph}$. D. (Educational Policy Studies and Evaluation) from University of Kentucky, Lexington, KY. A high school social studies teacher/administrator for 24 years. Then, she served Brescia University from 2005-2017 as Director of Education Graduate Program, and University of Phoenix Online since 2004. Presently a Doctoral Faculty for the College of Doctoral Studies and active participant in University of Phoenix Research Hub activities, such as Research Scholar for the Center for Educational and Instructional Technology Research (CEITR). Named Faculty Spotlight in May 2020. E-Mail: pakojie@email.phoenix.edu

Imhabibi Laroche, M.S. earned her B.S. (Business Management) from University of Kentucky, Lexington, KY. She also holds an M.S. (Human Resources Education) from University of Louisville, Louisville, KY. She understands the importance of education in the workforce. She is a Human Resources Director in Ocala, FL and has been in this field for over 10 years. She has been an Adjunct Professor at the College of Central Florida in Ocala, FL for three years. She also serves as Ocala Human Resource Management Association Workforce Readiness Chair. She monitors and evaluates concerns impacting the workforce readiness arena. E-Mail: imhabibiakojie@yahoo.com

Jane A. Schumacher, Ed.D., M.Ed. earned both her M.Ed. (Reading) and Ed.D. (Educational Leadership) from National-Louis University. She serves the College of Doctoral Studies, Education, University of Phoenix, as Lead Faculty Area Chair. She has been actively involved in teaching organizational development and executive leadership for over forty-nine years. Dr. Schumacher works as an organizational and executive leadership consultant on Maui and across Hawaii. She consults with schools, nonprofit organizations, and businesses and assists their boards and executive leaders in organizational goal setting. Her special interest in race, ethnicity, and culturally relevant leadership. She also serves as a Governing Board member for Hawaii Technology Academy, a public charter school with campuses on four Hawaiian Islands. EMail: jaschumacher@email.phoenix.edu

Manuscript received September 20, 2021

Final revision received December 12, 2021

Accepted December 24, 2021 